\title{
Utilization of personal protective equipment among sawmill workers in Ilorin metropolis, North-central Nigeria
}

\author{
*Uthman M.M.B. ${ }^{1,2}$, Folarori H.S. ${ }^{1}$, Rotimi B.F. ${ }^{1,2}$, Oloyede H. K. ${ }^{2}$, Uthman A.O.
}

\begin{abstract}
Objective: Wood dust becomes a potential health problem when wood particles from processes such as sanding, cutting, drilling, sawing or turning to sap wood becomes airborne. Occupational exposure in sawmills has suggested that workers in sawmills are at risk of developing allergenic disorders, cancers and lung disease. This study assessed the utilization of personal protective equipment among sawmill workers in Ilorin metropolis.
\end{abstract}

Methods: The study was descriptive cross-sectional by design assessing utilization of personal protective devices among sawmill workers in Ilorin metropolis involving 250 sawmill workers that were registered under the Ilorin Plank Sellers' Association. Data was collected using semi-structured, intervieweradministered questionnaires from the participants. The participants were recruited using multistage sampling technique. Data collected from the questionnaire were analyzed using SPSS 16.0 software package.

Results: The majority 144 (57.6\%) of the respondents own at least one of the personal protective devices while $134(53.6 \%)$ of the respondents utilized at least one of the personal protective devices. Only 54 $(21.6 \%)$ and $95(38.0 \%)$ of the respondents possess aprons and hand gloves respectively. The least owned PPEs were earmuffs (10.8\%) and safety boots (16.8\%). Among the 166 respondents who never use PPE, $86(74.1 \%)$ reported inconveniency as the reason for non-utilization of PPE.

Conclusion: There is a need to improve the level of knowledge, availability and use of protective devices among the workers through subsequent sensitization and enlightenment on the need to use PPE.

Key words: Sawmill, Utilization, Personal Protective Equipment, PPE, Workers

\author{
*Correspondence author \\ Uthman M.M.B. \\ http://orcid.org/0000-0002-3012-195X \\ Email: uthmanmb@yahoo.com
}

\footnotetext{
${ }^{1}$ Department of Epidemiology and Community Health, Faculty of Clinical Sciences, College of Health Sciences, University of Ilorin, Ilorin, Nigeria

${ }^{2}$ Department of Epidemiology and Community Health, University of Ilorin Teaching Hospital, Ilorin, Nigeria

${ }^{3}$ Warwick-Centre for Applied Health Research and Delivery (WCAHRD), Warwick Medical School, University of Warwick, Coventry, UK
} 


\title{
Utilisation d'équipements de protection individuelle chez les travailleurs de la scierie de la métropole d'Ilorin, dans le centre-nord du Nigéria
}

\author{
*Uthman M.M.B. ${ }^{1,2}$, Folarori H.S. ${ }^{1}$, Rotimi B.F. ${ }^{1,2}$, Oloyede H. K. ${ }^{2}$, Uthman A.O.
}

\section{Resume}

Objectif: La poussière de bois devient un problème de santé potentiel lorsque des particules de bois provenant de processus tels que le sablage, le découpage, le forage, le sciage ou la transformation en sève sont entraînées en suspension dans l'air. L'exposition professionnelle dans les scieries a suggéré que les travailleurs dans les scieries sont à risque de développer des troubles allergiques, des cancers et des maladies pulmonaires. Cette étude a évalué l'utilisation d'équipement de protection individuelle chez les travailleurs de la scierie de la métropole d'Ilorin.

Méthodes: L'étude était descriptive transversale par conception et évaluait l'utilisation de dispositifs de protection individuelle parmi les ouvriers de la scierie de la métropole d'Ilorin, impliquant 250 ouvriers de la scierie enregistrés auprès de la Ilorin Plank Sellers 'Association. Les données ont été collectées à l'aide de questionnaires semi-structurés, administrés par les intervieweurs, aux participants. Les participants ont été recrutés à l'aide d'une technique d'échantillonnage à plusieurs degrés. Les données recueillies à partir du questionnaire ont été analysées à l'aide du progiciel SPSS 16.0.

Résultats: La majorité des répondants $(57,6 \%)$ possèdent au moins un des dispositifs de protection individuelle, tandis que $134(53,6 \%)$ des répondants utilisaient au moins un des dispositifs de protection individuelle. Seuls $54(21,6 \%)$ et $95(38,0 \%)$ des répondants possèdent respectivement un tablier et des gants. Les EPI les moins possédés sont les cache-oreilles $(10,8 \%)$ et les bottes de sécurité (16,8\%). Parmi les 166 répondants qui n'utilisent jamais d'EPI, 86 $(74,1 \%)$ ont indiqué que l'inconvénient était la raison de la non utilisation d'EPI.

Conclusion: Il est nécessaire d'améliorer le niveau de connaissance, la disponibilité et l'utilisation de dispositifs de protection parmi les travailleurs par le biais d'une sensibilisation et d'une sensibilisation ultérieures sur la nécessité de porter un équipement de protection individuelle.

Mots clés: scierie, utilisation, équipement de protection individuelle, EPI, travailleurs

\author{
*Auteur principal \\ Uthman M.M.B. \\ http://orcid.org/0000-0002-3012-195X \\ Email:uthmanmb@yahoo.com
}

\footnotetext{
${ }^{1}$ Department of Epidemiology and Community Health, Faculty of Clinical Sciences, College of Health Sciences, University of Ilorin, Ilorin, Nigeria

${ }^{2}$ Department of Epidemiology and Community Health, University of Ilorin Teaching Hospital, Ilorin, Nigeria

${ }^{3}$ Warwick-Centre for Applied Health Research and Delivery (WCAHRD), Warwick Medical School, University of Warwick, Coventry, UK
} 


\section{INTRODUCTION}

Wood is one of the most important renewable resources in the world. Wood is "hard fibrous substance composing most of the stem and branches of a tree or shrub and covered by the bark" (1). Wood dust becomes a likely health problem when wood dust from procedures such as sanding, cutting, drilling, sawing or turning to sap wood becomes airborne; the total amount of airborne dust produced depends only on the total mass of wood removed, and not the type of wood (1).

Research on work-related contacts in sawmills has suggested that employees in sawmills are at risk of having allergenic disorders, cancers and lung disease. They are also exposed to synthetic chemicals used in these woods. Microorganisms associated with wood dust often elicit immunological response and the best known are those caused by moulds that may abundantly develop in suitable conditions on store woods (chips, planks) as a secondary wood infection. The inhalation of large amount of spores and fragment of fungi may cause in exposed workers strong antibody response and severe respiratory disorders (2).

Various studies in Nigeria have shown the role of job-related exposure to environmental contaminants in the incidence of respiratory disorders (3). Asthma is of particular concern. Most wood dusts can irritate the respiratory tract provoking asthma attacks in sufferer, although effective control of dust levels normally improves the problem. Some wood dusts can cause asthma as a specific allergic reaction. In addition, great levels of noise have been documented to be dangerous to workers. In a typical wood industry, noise level often exceed industry limits and may lead to hearing impairment (4).

Work related injuries and ill health are increasing. It is estimated that between 2 to 3 million people are routinely exposed to different hazards in the sawmill industry. Work related illhealth accounts for hundreds of thousands of premature deaths in wood-work industry (5).

Deafness, respiratory disorders (allergic rhinitis, asthma, chronic bronchitis, Sino-nasal Adenocarcinoma and impairment of lung function), musculoskeletal injuries, cardiovascular problems, kidney and liver damage are all common work related health problems in this industry (2). Asthma arising from result work place contact is a usually reported as occupational respiratory disorder. Assessment by the American thoracic society in the year 2004 reported that $15-23 \%$ of new cases of asthma in adults are job related (6).

Attendant disabilities due to work related injuries have many consequences for individuals and the society, particularly for personnel suffering the effects at an early age. This makes prevention of work-related injuries and ill health a development issues. The knowledge of sawmill workers on occupational hazards was low (7). Workers are lack knowledge and equipment to apply health and a safety management system, whilst the usage of personal protective equipment, information, training, coordination, planning and responsibilities for prevention are extremely weak (8).

Awareness of positive values of safe working environment in terms of economic benefits and social justice is either low or nonexistent. Very often, safety concerns is seen as a burden in a highly competitive race to achieve the lowest possible production cost (8). The objective of the study was to assess the utilization of personal protective equipment among sawmill workers in Ilorin metropolis.

\section{MATERIALS AND METHODS}

The study was conducted in Ilorin metropolis, capital of Kwara State, North-central Nigeria. Ilorin metropolis has 3 Local Government Areas namely; Ilorin West with twelve wards, Ilorin south with eleven wards and Ilorin East with twelve wards.

The study was descriptive cross-sectional by design assessing utilization of personal protective devices among sawmill workers in Ilorin metropolis, Kwara State Nigeria. The minimum sample size was determined using formula (9) for calculating sample size in population greater than 10,000 .

$$
\mathrm{n}=\frac{\mathrm{Z}^{2}}{\mathrm{~d}^{2}} \mathrm{pq}
$$

Where

$\mathrm{n}=$ the desired sample size $>10,000$

$\mathrm{z}=$ standard normal deviate $1.96(95 \%$ C.I $)$

$p=$ prevalence or proportion of sawmill workers that have knowledge of occupational hazards and utilization of personal protective equipment, $20 \%=0.2$ (from previous study) $(10)$.

$$
\begin{aligned}
& \mathrm{q}=1-\mathrm{p} \\
& 1-0.2=0.8 \\
& \mathrm{~d}=\text { degree of } \operatorname{accuracy}(0.05) \\
& \text { Therefore, } \mathrm{n}=\left({\underline{1.96)^{2}}}^{\frac{\mathrm{x} 0.2 \times 0.8}{(0.05)^{2}}}\right. \\
& =\frac{0.614656}{0.0025} \\
& =245.6
\end{aligned}
$$




$$
=246
$$

10,000

Formula for a population less than

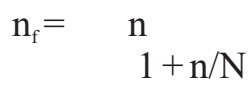

$\mathrm{n}_{\mathrm{f}}=$ desired sample size (population less than $10,000)$

$\mathrm{n}=$ desired sample size (population more than 10,000)

$\mathrm{N}=$ estimate of the population size $=1,300$

$$
\begin{aligned}
\mathrm{n}_{\mathrm{f}}=\frac{246}{1+\frac{246}{1300}} \\
=246 \\
1+0.1892 \\
=206
\end{aligned}
$$

Sample size was rounded up to 250 to increase the power of the study.

A total of 250 sawmill workers that were registered under the Ilorin Plank Sellers' Association and working at a sawmill for at least 6 months were included in the study using multistage sampling method thus: Through simple random sampling method by balloting, 6 sawmills were selected from a list of 13 sawmills in Ilorin. Then, proportional allocation was used to determine the total number of respondents that were interviewed from each of the selected sawmills.

At each of the sawmill, systematic sampling technique was used to select eligible respondents. The sampling frame used was the register book which contain the list of the workers in each of the sawmill visited. The first responded was selected using simple random sampling. After selection of $1^{\text {st }}$ respondent, subsequent consenting eligible respondents were selected after calculated sampling interval for the sawmill until adequate sample size was attained. Where there was unwilling respondent, the next person on sampling frame was then selected, while still maintaining the sampling interval. This procedure was repeated in all other sawmill taken into consideration their respective sampling intervals.

The research instrument was a semistructured, interviewer-administered questionnaire. Pre-testing of the questionnaire was carried out among 30 randomly selected sawmill workers in Offa Local Government Area of Kwara State. Data collected from the questionnaire were analyzed using SPSS 16.0 software package. Ethical approval for the study was obtained from the Faculty of Clinical Sciences, University of Ilorin Ethical Review Committee.

\section{RESULTS}

The age distribution of respondents ranged from 15 to 74 years while the mean age $( \pm$ s.d.) was $36.0( \pm 12.9)$ years. The highest percentage of respondents was between the age group of 15-24 years, which accounts for $20.4 \%$ of the population. Majority of the respondents; $123(49.2 \%)$ had over 10 years work experience at sawmill. Table 1.

The majority $144(57.6 \%)$ of the respondents own at least one personal protective device while $134(53.6 \%)$ of the respondents utilized at least one personal protective device. Only $54(21.6 \%)$ and $95(38.0 \%)$ of the respondents possess aprons and hand gloves respectively. The least owned PPEs were earmuffs (10.8\%) and safety boots (16.8\%). Table 2.

Few $77(28.4 \%)$ of the respondents use PPE frequently. Among the 166 respondents who never used PPE, $86(74.1 \%)$ reported inconveniency as the reason for non-utilization of PPE. Table 3.

The relationship between the work section of respondents and utilization of personal protective equipment was found to be statistically significant $(\mathrm{P}=0.0012)$. That is, the utilization of personal protective equipment among the respondents varies significantly based on their work sections (department) at the sawmills. Table 4.

The association between work duration (in hours) of respondents and utilization of personal protective equipment was not statistically significant $(p=0.050)$, meaning that the utilization of personal protective equipment among the respondents did not vary significantly based on their work duration per day (in hours). The relationship between the work experience of respondents and utilization of personal protective equipment was found to be statistically significant $(\mathrm{P}=0.000)$, implying that the utilization of personal protective equipment among the respondents varies significantly based on their work experience (in years). Table 5.

\section{DISCUSSION}

The work-related injuries and waste arising from wood handling including wood dust, moulds, formaldehyde and noise often have deleterious health effect. Research on 
occupational exposures in sawmill implied that workers in sawmills are at risk of ill health. In Nigeria, various studies have shown the role of occupational exposure to environmental pollutants in the incidence of respiratory diseases (3). Another example is the high levels of noise that have long been recognized by industrial safety technicians as unsafe to workers. In a typical wood industry, decibel levels often exceed industry limits and may cause hearing loss (4).

The results also showed that most of the respondents were machine operators, representing $50.4 \%$ (126) of the respondents. More so, all the respondents were males, with $54.8 \%$ of them with secondary education; just as was observed in studies conducted among saw mill workers in North Central Nigeria. Therefore, sawmill work is largely a vocation for averagely educated young men in Ilorin. This trend suggests that there is a gender bias towards this kind of work in Nigeria, which could be due to its strenuous and hazardous nature.

In this study the largest percentage of respondents spent not less than $10-12$ hours at work and some work less than 8 hours which correspond with the normal 8-hour workday standard term exposure limit referred to in similar studies (1). Some of the workers spent less than 8 hours per day due to fluctuation in electrical power supply. Those that spent more than 8 hours per day may experience more stress at the end of the day and this can also increase the risk of injury at workplace. This is because some run night shifts and overtime in order to utilize the night time power arrangement made with PHCN (Power Holding Company of Nigeria). Surveys have indicated that a large proportion of machine operators had long-term health problems that are connected to their longer hours at work(4). These problems arise from spending excessive periods of time in a machine, where operators continuously carry out the same task and working with minimal rest. Noise exposure cases in the workplace often take years to become apparent. The long term exposure to noise from machine can lead to industrial deafness.

Availability and use of safety devices were also poor. In this study, up to $57 \%$ of the respondents own one form of protective device. Majority of the workers did not make use of the available protective gadgets while only about $28.4 \%$ of them regularly utilize some protective devices they consider necessary like- safety boots, hand gloves and nose guards. This is similar to studies in where less than $20 \%$ and
$32 \%$ of the sawmill workers used PPE in Ilorin(10) and Ile-Ife(11) respectively. However, the utilization of PPE was much higher as reported by a study done in Ghana among workers of small scale sawmill workers where only $30 \%$ of the respondents never use any PPE(12). This mighty be due to stricter regulatory framework in the work premises. of the For cost, some of the employers did not provide the devices and in situation where it is available, majority of the respondents found it unnecessary and others (74.1\%) said it was not convenient when used. This is compared with the study done in Benin City, Nigeria (3) which indicated that less than $5 \%$ of the workers wore facemasks, protective clothing or boots at work.

\section{CONCLUSION}

The utilization of personal protective equipment was poor among sawmill workers in Ilorin where almost half of the respondents were not using any the personal protective equipment. Inconveniency during use and cost of procurement were the main reasons for nonutilization of the personal protective equipment.

Recommendations: There is a need to improve the level of knowledge, availability and use of protective devices among the workers through subsequent sensitization and enlightenment on the need to use PPE. This economically viable group needs to be properly and adequately educated on workplace hazards, the types and proper use of the different protective devices in order to protect their health and lives.

Conflict of interest: The authors declare no conflict if interest.

\section{REFERENCES}

1. Alwis KU. Occupational Exposure to Wood Dust1998 06/01/2019]:[21-53 pp.]. Available from: http://hdl.handle.net/2123/392.

2. Dutkiewicz J, Skorska C, Dutkiewicz E, Matuszyk A, Sitkowska J, Krysinska-Traczyk E. Response of sawmill workers to work-related airborne allergens. Annals of agricultural and environmental medicine : AAEM. 2001;8(1):8190.

3. Ugheoke AJ, Ebomoy ML, Iyawe VI. Influence of smoking on respiratory symptoms and lung fuctions indices in sawmill workers in Beninu city, Nigeria. Nig J Physical 2006;21:49-54.

4. Koehncke N, Taylor M, Taylor C, Harman L, Hessel PA, Beaulne P, et al. An investigation of noise levels in Alberta sawmills. Am J Ind Med. 2003;43(2):156-64.

5. Huff J. Sawmill chemicals and carcinogenesis. 
Environmental health perspectives. 2001;109(3):209-12.

6. Nathell L, Malmberg P, Lundback B, Nygren A. Impact of occupation on respiratory disease. Scandinavian journal of work, environment \& health. 2000;26(5):382-9.

7. Agbana BE, Joshua AO, Daikwo MA, Metiboba LO. Knowledge of occupational hazards among sawmill workers in Kwara state, Nigeria. The Nigerian postgraduate medical journal. 2016;23(1):25-32.

8. Internal Labour Organization. Occupational Health Services in Developing Countries: Occupational Health Safety and Health Series No. 7. 1967.p. 187.

9. Araoye MO. Sample size determination. Research methodology with statistics for health and social sciences. 1st ed. Ilorin: Nathadex Publishers; 2004. p. 115-20.
10. Osagbemi GK, La Kadri RT, Aderigbgbe SA. Awareness of Occupational Hazard, Health Problems and Safety measures among sawmill workers in North Central Nigeria. TAF Prev Med Bull. 2010;9(4):325-8.

11. Faremi FA, Ogunfowokan AA, Mbada C, Olatubi MI, Ogungbemi AV. Occupational hazard awareness and safety practices among Nigerian sawmill workers. International Journal of Medical Science and Public Health. 2014;3(10):1244-8.

12. Ochire-Boadu K, Kusi E, Lawer EA Occupational Hazards And Safety Practices: A Concern Among Small Scale Sawmilling Industries In Tamale Metropolis, Ghana. International Journal of Scientific \& Technology Research. 2014;3(10):234-6. 
Table 1: Socio demographic characteristics of respondents $(\mathrm{N}=\mathbf{2 5 0})$

\begin{tabular}{lll}
\hline Variable & Frequency & Percentage \\
\hline Age Group & & \\
$15-24$ & 51 & 20.4 \\
$25-34$ & 74 & 29.6 \\
$35-44$ & 72 & 28.8 \\
$45-54$ & 28 & 11.2 \\
$55-64$ & 17 & 6.8 \\
$\quad 65-74$ & 8 & 3.2 \\
Mean \pm SD & $36.0 \pm 12.9$ & \\
Level of Education & & \\
$\quad$ None & 5 & 2.0 \\
Primary & 21 & 8.4 \\
Secondary & 137 & 54.8 \\
Tertiary & 87 & 34.8 \\
Work Experience & & \\
$<5$ years & 58 & 23.2 \\
5-10 years & 69 & 27.6 \\
Over 10 years & 123 & 49.2 \\
Duration (hours) & & \\
$<4$ & 19 & 7.6 \\
$4-6$ & 33 & 13.2 \\
$7-9$ & 62 & 24.4 \\
$10-12$ & 136 & 54.4 \\
\hline
\end{tabular}

Table 2: Ownership and Utilization of PPE by the respondents ( $\mathrm{N}=\mathbf{2 5 0})$

\begin{tabular}{lll}
\hline PPE & Ownership (\%) & Utilization (\%) \\
\hline Any PPE & $144(57.6)$ & $\mathbf{1 3 4}(\mathbf{5 3 . 6 )}$ \\
Apron & $54(21.6)$ & $40(16.0)$ \\
Hand gloves & $95(38.0)$ & $110(44.4)$ \\
Safety boots & $42(16.8)$ & $42(16.8)$ \\
Face mask & $60(24.0)$ & $54(21.6)$ \\
Use of Ear muffs & $27(10.8)$ & $26(10.4)$ \\
Use of Eye goggles & $71(28.4)$ & $63(25.2)$ \\
\hline
\end{tabular}

Table 3: Frequency of use, motivation and barrier to utilization of PPE by the respondents $(\mathrm{N}=\mathbf{2 5 0})$

\begin{tabular}{lll}
\hline Utilization of PPE & Frequency & Percentage \\
\hline Frequency of use & & \\
Regularly & 71 & 28.4 \\
Occasionally & 63 & 25.2 \\
Never & 116 & 46.4 \\
Motivation to use (n=134) & & \\
Mandated & 56 & 22.4 \\
Informed & 192 & 76.8 \\
Others & 2 & 0.8 \\
Reasons for non-utilization $(\mathbf{n}=\mathbf{1 1 6})$ & & \\
Cost & 30 & 25.9 \\
Not convenient for work & 86 & 74.1 \\
\hline
\end{tabular}


Table 4: Relationship between Work Section and Utilization of PPE

\begin{tabular}{|c|c|c|c|c|}
\hline Work section & Yes $(\%)$ & No $(\%)$ & $\mathbf{X}^{2}$ & P-value \\
\hline Workshop & $86(58.1)$ & $62(41.9)$ & & \\
\hline Transport/Dispatch & $14(28.6)$ & $35(71.4)$ & 15.934 & 0.0012 \\
\hline Sawmill shop/Administrative & $29(64.4)$ & $16(35.6)$ & & \\
\hline Maintenance & $5(62.5)$ & $3(37.5)$ & & \\
\hline
\end{tabular}

Table 5: Relationship between Work Duration and Utilization of PPE

\begin{tabular}{lcllc}
\hline \multicolumn{1}{c}{ Work Duration (in hours) } & Yes $\mathbf{( \% )}$ & No $(\%)$ & $\mathbf{X}^{2}$ & P-value \\
\hline$<4$ & $16(84.2)$ & $3(15.8)$ & & \\
$4-6$ & $21(63.6)$ & $12(36.4)$ & & \\
$7-9$ & $40(64.5)$ & $22(35.5)$ & $\mathbf{3 3 . 8 8 9}$ & $\mathbf{0 . 0 5 0}$ \\
$10-12$ & $57(41.9)$ & $79(58.1)$ & & \\
Work Experience (in years) & & & & \\
$<5$ years & $31(53.4)$ & $27(46.6)$ & & \\
$5-10$ years & $60(65.2)$ & $32(34.8)$ & $\mathbf{7 2 . 1 4 4}$ & $\mathbf{0 . 0 0 0}$ \\
Over 10 years & $43(43.0)$ & $57(57.0)$ & & \\
\hline
\end{tabular}

